\title{
Subfossil Cladocera and pollen as indicators of natural and anthropogenic trophic changes of Lake Jelonek (Tuchola Forest, $\mathbf{N}$ Poland) during the Holocene
}

\author{
Edyta Zawisza,${ }^{1 *}$ Anna Filbrandt-Czaja,${ }^{2}$ Alexander Correa-Metrio ${ }^{3}$ \\ ${ }^{1}$ Institute of Geological Sciences, Polish Academy of Sciences, Research Centre in Warsaw, ING PAN, Twarda 51/55, PL-00818 Warsaw, \\ Poland; ${ }^{2}$ Chair of Geobotany and Landscape Planning, Faculty of Biology and Environmental Protection, Nicolaus Copernicus University \\ in Toruń, Lwowska 1, Toruń PL-87100, Poland; ${ }^{3}$ Instituto de Geología, Universidad Nacional Autónoma de México, Ciudad Universitaria, \\ 04510 D.F., Mexico
}

*Corresponding author: ezawisza@twarda.pan.pl

\begin{abstract}
Lake Jelonek is a small lake located in central northern Poland, in the Tuchola Forest. The sediments of the lake represent a natural archive that offers insights into the natural history of the region from the Late Glacial to present. In winter 2002 , a $1330 \mathrm{~cm}$ long sediment core was recovered from the deepest part of lake. Using a multiproxy approach (cladocerans, pollen and basic geochemistry), we reconstructed trophic status changes through the last $\sim 15,000$ years. Special attention was devoted to the evaluation of nutrient contributions to the lake from natural and anthropogenic sources. The Cladocera analyses yielded a total of 29 species belonging to five families (Bosminidae, Daphniidae, Leptodoridae, Chydoridae, Sididae), with planktonic species representing more than $60 \%$ of Cladocera relative abundance throughout the core. The pollen results suggested four periods of increased human activity, so-called settlement phases. The first traces of human activity in the basin of Lake Jelonek appeared in the Atlantic period and were related with Mesolithic and Neolithic settlements. The second (Bronze Age) and the third (Iron Age) settlement phases are well marked by the paleolimnological proxies studied. This time period clearly manifested on the lake waters as an increasing trophy level probably caused by human-associated discharges of nutrients to the lake. After the third settlement phase cladoceran data indicated a significant decrease in the lake trophic level and the pollen data showed a recovery of forest cover. The fourth period of human economic activity during the early Middle Age was characterized by deforestation associated with land reclamation for grazing and cultivation of cereals, and the subsequent nutrient enrichment of lake waters. According to our results, the biological development of Lake Jelonek was determined by climate changes from Late Glacial up to the Atlantic period. Contrastingly, the most important driver for the lake development though the middle and late Holocene has been human activity within the lake catchment. The recovery of the lake trophic level during the last century, which is primarily related to extensive afforestation of the lake catchment, highlighted the importance of land use in the conservation of healthy water bodies
\end{abstract}

Key words: Trophic changes; subfossil Cladocera; pollen analysis; Tuchola Forest; paleolimnological multi-proxy analysis; Holocene.

Received: August 2016. Accepted: November 2016.

\section{INTRODUCTION}

The increasing trophic status or eutrophication of water bodies is a modern worldwide problem. Nowadays, rapid increases of lake trophic levels can be easily observed in a large number of lake ecosystems (Schmidt et al., 2000; Richerson et al., 2008). The natural dynamics of many lake ecosystems, especially those located in urban and agricultural areas, have been highly modified by human activity. The effects of human related nutrient supply have been widely investigated and discussed (Joye, 2006; Smith and Schindler, 2009; Gałka et al., 2014). It is common opinion that major human impacts on lake trophic processes began in the Middle Age or in the era of the Industrial Revolution (starting from the $19^{\text {th }}$ century). However, paleolimnological studies have demonstrated that ancient cultures with a lesser techno- logical development, such as the Neolithic or even older Mesolithic human groups, were also able to substantially impact lake ecosystems (Goransson, 1986; Latałowa, 1994, 2003). In addition, changes in lake trophic level have also resulted from natural processes (mostly related to climate changes), and from their interactions with anthropogenic influence (Zawisza and Szeroczyńska, 2007; Nevalainen et al., 2013; Grabowska et al., 2015). As a result, the assessment of the relative influence of human and natural impacts on lakes in past times and at present is critical for establishing viable management plans for these ecosystems. In this sense, paleolimnological studies have substantially contributed to understanding the long term dynamics of eutrophication processes, e.g. in discriminating the origin of nutrients (human or natural). Of special interest is the assessment of the time span required by impacts and processes to act upon water bodies and produce 
significant changes in their trophic status. It is well-known that lake-catchment systems respond physically, chemically and biologically to natural climatic changes as well as to environmental changes caused by human activities (O'Sullivan, 1983; Ralska-Jasiewiczowa et al., 2003). Lake ecosystems most rapidly and clearly respond to natural or anthropogenic nutrient supply (Smol, 2008).

One of the best and most powerful biological proxies which can be studied in lake sediments for the reconstruction of lake trophic evolution, both related to climate and humans, is represented by Cladocera remains (Zawisza and Szeroczyńska, 2007; Chen et al., 2010). Cladocera, as a key component of zooplankton, represent a biotic component of the lake ecosystem and provide important information on the lake environment (Lampert and Sommer, 2007). On the other hand, pollens represent one of the best and most important sources of information about changes in terrestrial vegetation and land use. The interpretation of pollen data offers the potential for reconstructing human impact on the lake catchment in prehistoric times (Behre, 1986; Birks et al., 1988). Thus, the combination of subfossil Cladocera studies and palynological analyses can enhance the reliability of reconstruction of past water trophic level and land-use within the lake catchment.

In this study, we present the reconstruction of changes in trophic status of Lake Jelonek (N Poland) from its origin until modern times, with the objective of assessing the relative contribution of natural and anthropogenic sources of nutrients on the basis of subfossil Cladocera and pollen analysis. The long sediments record of Lake Jelonek, which covers a time span of $\sim 14,000$ years, offered a good opportunity to understand the relative contribution of climate and human activity to the development and dynamics of aquatic ecosystems in this region. From the Late Glacial to the early Holocene the record provided insights into the dynamics of a system driven mainly by natural forces. Contrastingly, the study of the regional and local conditions from the mid Holocene to modern times provided scenarios for different human influences on the landscape. Thus, this time period mostly contributed to understanding lake dynamics under contrasting technological systems of land use. Pollen indicator taxa provided information on the main modes of human land use of the lake catchment, while basic geochemistry and Cladocera provided insights into the impact of human activities on the trophic status of the lake.

\section{METHODS}

\section{Study site}

Lake Jelonek is located in central northern Poland, in the south-eastern part of Tuchola Forest (Fig. 1 a,b), at an altitude of $91 \mathrm{~m}$ asl The lake is of glacial origin and lo- cated in a NW-SE oriented glacial channel on the ice line of the Last Glacial Maximum close to the Wda River (Błaszkiewicz, 2006). Lake Jelonek is a small shallow water body, with an area of 20.9 ha and an average depth of $4.5 \mathrm{~m}\left(\mathrm{z}_{\max } 13.8 \mathrm{~m}\right.$, Fig. 1c). The length of the shoreline is $2250 \mathrm{~m}$ and the shoreline development ratio is small (1.39). The water $\mathrm{pH}$ is circa neutral ( 7.2), and the conductivity is around $300 \mu \mathrm{S} \mathrm{cm}^{-1}$. The modern trophic status of Lake Jelonek has been determined as mesotrophic (Jańczak, 1997). The Tuchola Forest region is characterized by a climate from the group D - continental/microthermal climates (McKnight and Darrel, 2000; Przybylak et al., 2010; Woś, 2010). Mean annual air temperature and precipitation are $7.6^{\circ} \mathrm{C}$ and $558 \mathrm{~mm}$, respectively (Filbrandt-Czaja, 2009). The winter lasts around 70 days, with a mean temperature of $-3.2^{\circ} \mathrm{C}$. The duration of ice-cover is approximately 3 months, from the beginning of January until the end of March, with a growing season of approximately 210 days per year. The modern vegetation is dominated by the monoculture of pine, arising from a one-way human activity. Nowadays, area the natural forest ecosystems are almost absent in the Tuchola Forest (Boiński, 1992).

\section{Sampling and analyses}

In winter 2002, a $1330 \mathrm{~cm}$ long sediment core was recovered from Lake Jelonek using a Livingstone-type corer. The sampling point $\left(53^{\circ} 46.1^{\prime} \mathrm{N}, 18^{\circ} 23.5^{\prime} \mathrm{E}\right)$ was located in the deepest part of the lake (water depth $\sim 13.8$ m, Fig. 1c). After coring, the sediment was packed and transported to the laboratory for a lithological description, and a subsampling procedure, which was carried out at 5 to $10 \mathrm{~cm}$ intervals. Subsamples were analysed for subfossil Cladocera, pollen, and basic geochemistry.

Fifteen points along the core were sampled for the radiocarbon dating of the sedimentary sequence. Twelve terrestrial plant macrofossils samples were ${ }^{14} \mathrm{C}$ dated by AMS (Accelerator Mass Spectrometry), whereas three of bulk sediment samples were analyzed by ${ }^{14} \mathrm{C}$ conventional methods (Stuiver and Polach, 1977). All radiocarbon analyses were carried out at GADAM Absolute Dating Methods Centre, Gliwice, Poland (Tab. 1). Ages were calibrated according to the IntCal 13 curve (Reimer et al., 2013). Selected pairs of depths and calibrated ages were used to fit a Bayesian age-depth model using Bacon (Blaauw and Christen, 2011). Carbonate and organic matter content were measured in 76 sediment subsamples $\left(10 \mathrm{~cm}^{3}\right)$, which were firstly dried at $105^{\circ} \mathrm{C}$ and homogenized in an agate mill, and then subjected to a two-step procedure (Bengtsson and Enella, 1986). In the first reaction, organic matter was oxidized at $550^{\circ} \mathrm{C}$ to carbon dioxide and ash. In the second reaction, carbon dioxide was evolved from carbonate at $925^{\circ} \mathrm{C}$, leaving oxide. The carbonate content was calculated using the relationship Carb $=1.36 \mathrm{LOI}_{925}$, where 

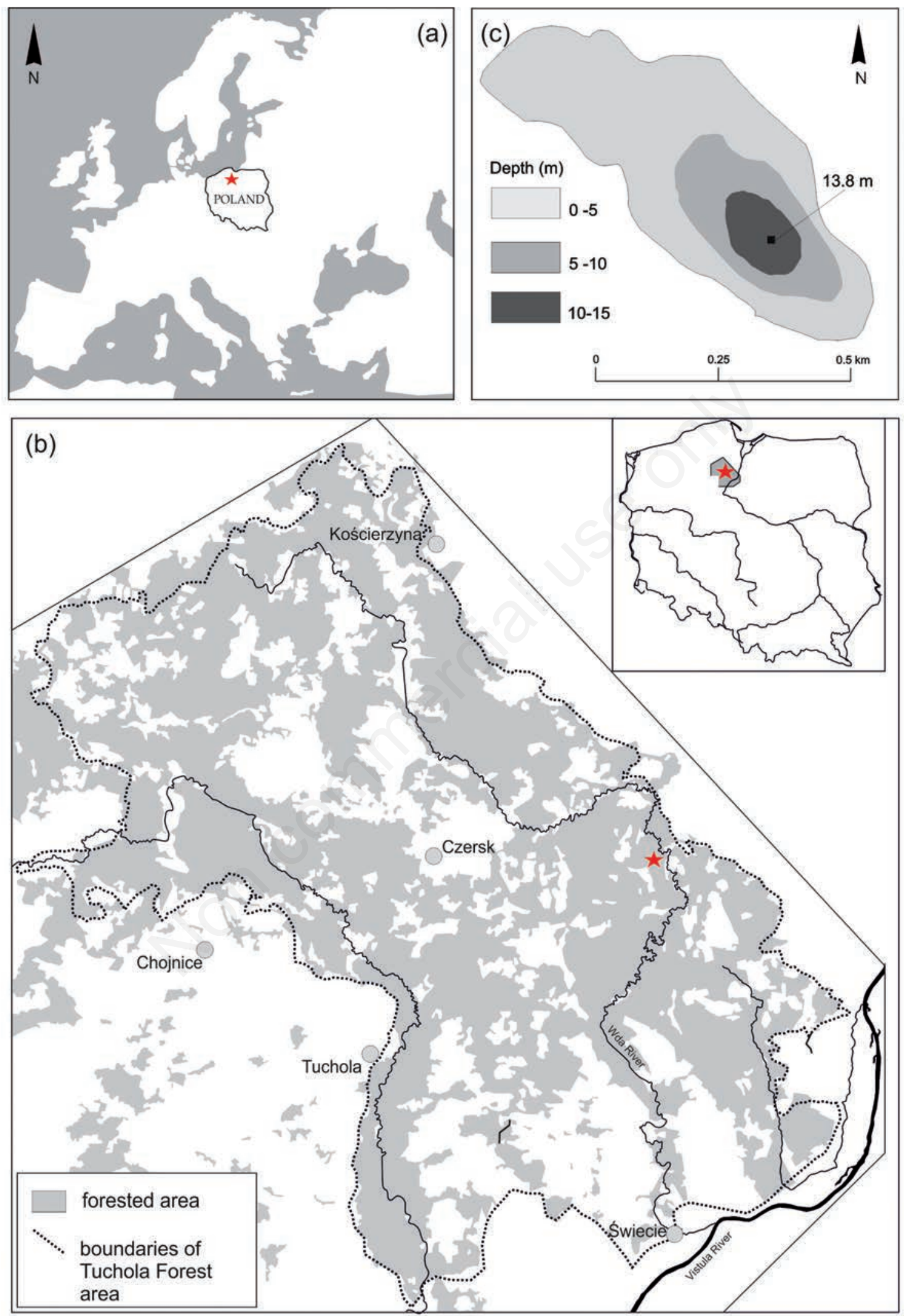

Fig. 1. Location of Lake Jelonek. a) Location in Europe. b) Location of Lake Jelonek (asterisk) in the Tuchola Forest area, boundaries of Tuchola Forest area according to Kowalewski (2002). c) Bathymetric map of Lake Jelonek with the coring point marked at the lake deepest point. 
$\mathrm{LOI}_{925}=\mathrm{CO}_{2}$ evolved from the sample, as defined by Heiri et al. (2001).

The subfossil Cladocera analysis was conducted on 143 sediment subsamples $\left(1 \mathrm{~cm}^{3}\right)$, which were processed according to the standard method proposed by Frey (1986). Samples were boiled in a $10 \%$ solution of $\mathrm{KOH}$, and later left for half an hour in a magnetic stirrer to eliminate organic matter. The residue was washed with distilled water and sieved through a $35 \mu \mathrm{m}$ mesh. The final residue was dissolved in $10 \mathrm{~mL}^{-1}$ distilled water. For every microscope slide, $0.1 \mathrm{~mL}$ of final solution was used and the identification of remains was made at magnifications of 100x, 200x, and 400x, using an OLYMPUS BX40 transmitted-light microscope. Two to four slides (minimum of 200 remains) from each sample were counted. All cladoceran remains were counted (head shields, shells, postabdomens, ephippia), and complete individuals were added up from body parts. Cladocera identification was based on Szeroczyńska and Sarmaja-Korjonen (2007) and Flössner (2000).

Palynological analyses were conducted on 137 sediment subsamples $\left(1 \mathrm{~cm}^{3}\right)$ accounting at a resolution of 5$10 \mathrm{~cm}$. Samples were treated to eliminate non-pollen components of the sediment according to standard protocols (Berglund and Ralska-Jasiewiczowa, 1986), and acetolysis was conducted to remove cellulose. Two Lycopodium tablets were added to each sample prior to acetolysis in order to allow the calculation of absolute concentrations of sporomorphs (Stockmarr, 1971). Treated samples were stained with fuchsine and immersed in glycerine, and sporomorphs were counted under a microscope Zeiss at 340 and 680 magnifications. At least 1000 pollen grains were counted from each sample, with total pollen counts being lower only in bottom samples, because of very low pollen amounts in the deepest core section. Identification of pollen grains and spores was based on Erdtman et al. (1961), Faegri and Iversen (1989), Reille (1992), and Beug (2004). Regional pollen assemblages reported as markers of chronostratigraphic units for the studied time period were used to refine the chronology after Filbrandt-Czaja (2009).

All arboreal (AP) and herbaceous (NAP) taxa were included in the pollen sum that served as the basis to calculate pollen percentages. Simplified pollen diagrams were constructed using the $\mathrm{C} 2$ software (Juggins, 2007) to summarize the changes of selected taxa, mainly trees and herbaceous plants considered as indictors of human impact (Behre, 1981). The identified taxa were subdivided into six major ecological groups (after Berglund 1969): i) trees preferring damp soils, e.g. Alnus; ii) highly competitive and shade-tolerant trees; iii) trees immigrating during late Holocene, e.g. Fagus, Carpinus, Picea; iv) scarcely competitive and light-demanding trees, often belonging to the primary stage of Holocene forest successions; v) apophytes, i.e. shrubs and herbs favoured by man; vi) an- thropochors, i.e. herbs and graminoids introduced by man.

Core depth are indicated in all stratigraphic plots as $\mathrm{cm}$ below the lake surface (bls), in order to allow comparison with previous paleolimnological studied on Lake Jelonek (Filbrant-Czaja 2009; Błaszkiewicz, 2006).

\section{RESULTS}

\section{Sediment lithology and geochemistry}

The sediments of Lake Jelonek were mainly composed of detritus and calcareous gyttja (Fig. 2). Below $2705 \mathrm{~cm}$ bls, the sediment consisted of light beige sand. Between 2705 and $2695 \mathrm{~cm}$ bls, the sediment was dominated by sandy silt (ca. $20 \% \mathrm{CaCO}_{3}$ content, Fig. 2), topped by a $5 \mathrm{~cm}$-thick layer of sand $(2695-2690 \mathrm{~cm})$. From 2690 to $2580 \mathrm{~cm}$ bls, the sediment was composed of light grey silt with an increasing carbonate content reaching up to $40 \%$. From 2580 to $2500 \mathrm{~cm}$ bls, sediment was characterized by dark olive-beige silt detritus gyttja (organic matter ca. $50 \%, \mathrm{CaCO}_{3}>10 \%$ ). From 2500 to $2400 \mathrm{~cm}$ bls, light grey detritus gyttja with a very low content of $\mathrm{CaCO}_{3}>5 \%$ was identified. Between 2400 and $2160 \mathrm{~cm}$ bls calcareous-detritus gyttja with occasional laminations occurred. Dark detritus gyttja with a high content of organic matter and low $\mathrm{CaCO}_{3}$ dominated from 2160 to $1800 \mathrm{~cm}$ bls. From 1800 to $1530 \mathrm{~cm}$ bls, sediments were composed of dark calcareous-detritus gyttja with occasional lamination. From 1530 to $1480 \mathrm{~cm}$ bls, the sediment was dark detritus gyttja, whereas the uppermost part of the sedimentary deposit (1480 to1380 cm bls) consisted of dark brown-olive, calcareous detritus gyttja, with high $\mathrm{CaCO}_{3}$ content (on average ca. $45 \%$ ).

\section{Chronology}

The age-depth model was constructed using 12 radiocarbon dates (Tab. 1) and 5 ages defined by the appearance of biostratigraphic markers of the Central Europe chronostratigraphy (Mangerud et al., 1974; Walanus and Nalepka, 2010). Three pollen-based dates were rejected due to stratigraphic inconsistencies. Thus, a total of 17 depth-age data pairs were used to fit the Bayesian agedepth model (Fig. 3), yielding a basal age of $\sim 14,000$ calibrated years before present (cal yr BP) for the whole sedimentary sequence.

\section{Subfossil Cladocera}

A total of 29 Cladocera species belonging to five families were identified in the sedimentary sequence of Lake Jelonek. Planktonic species were represented by the families Bosminidae, Daphniidae, and Leptodoridae, as well as by littoral species of Chydoridae and Sididae. Planktonic species accounted to more than $60 \%$ of total Clado- 
cera relative abundance, thus representing the major component of the Cladocera assemblages during the last 14,000 years (Fig. 4). Six Cladocera Assemblages Zones (CAZ) were empirically distinguished based on the species composition and changes in the relative abundance of the species (Fig. 4).

\section{CAZ I, before 12900 cal yr BP $(2705-2640 \mathrm{~cm}$ bls $)$}

The initial phase of Lake Jelonek development was characterized by low Cladocera abundance and low species richness. Eight Cladocera species were identified, with a maximum concentration of 800 specimens per $\mathrm{cm}^{3}$ of sediment (Fig. 4). Pelagic species, such as Bosmina longirostris (O.F. Müller, 1757) and Daphnia longispina group (O.F. Müller, 1785), were dominant (with a relative abundance over $80 \%$ ). Littoral species tolerant to cold waters, i.e. Alona affinis (Leydig, 1860), Chydorus sphaericus (O.F. Müller, 1785), Acroperus harpae (Baird, 1835), Alonella nana (Baird, 1843), were also present.

\section{CAZ II 12900 - 9600 cal yr BP (2640-2540 cm bls)}

This phase was characterized by a sudden increase in Cladocera abundance. A total of 20 species were identified, consisting mainly in planktonic taxa, i.e. Bosmina longirostris, Bosmina (E.) coregoni (Baird, 1857), Daphnia pulex group (Leydig, 1860), and Leptodora kindti (Focke,

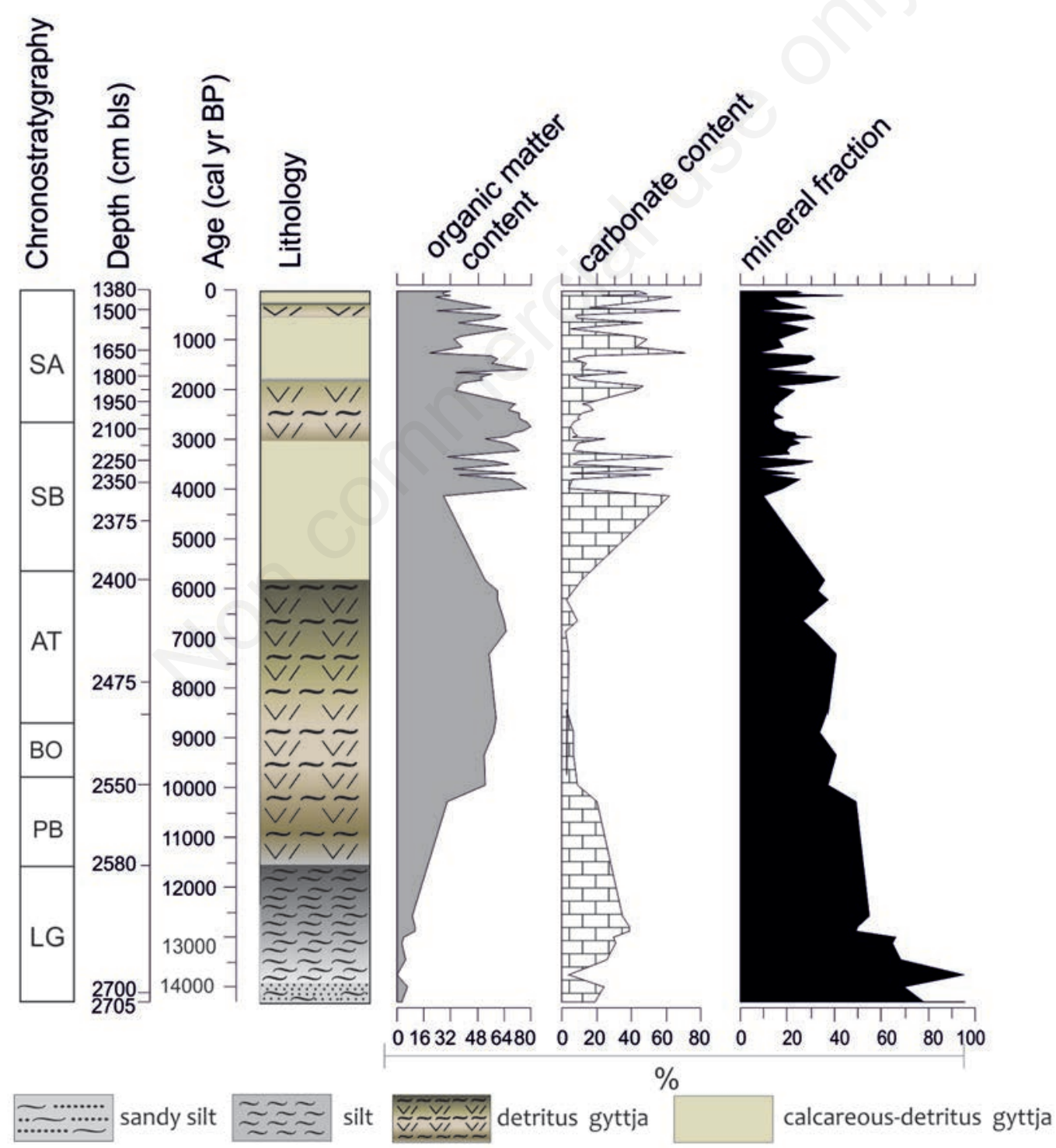

Fig. 2. Schematic lithology and depth profiles of organic matter, carbonate and mineral fraction content in the sediments from Lake Jelonek; bls, below lake surface. 
1844 ), which accounted for over than $60 \%$ of total cladoceran remains (Fig. 4). Noteworthy is the presence of species associated to warm waters, such as Camptocercus rectirostris (Schoedler, 1862), and Pleuroxus trigonellus (O.F. Müller, 1776), and of species living in association with aquatic plants and having higher edaphic requirements, such as Chydorus sphaericus and species from the genera Alona (Baird, 1843) and Alonella (Sars, 1862).

\section{CAZ III 9600 - 6200 cal yr BP (2540 - $2420 \mathrm{~cm}$ bls $)$}

Cladocera species richness increased through this phase to up to 23. Pelagic Bosmina longirostris, Bosmina (E.) coregoni, and Bosmina (E.) longispina dominated the cladoceran community. The latter species showed its first appearance and reached its maximum abundance through the entire sediment record within this zone. A total of 17 littoral species were identified in CAZ III, the majority being reported as occurring in association with aquatic plants, such as Alona and Alonella spp. as well as Acroperus harpae, Pleuroxus sp. and Sida crystallina (Straus, 1820). Three species showed their first appearance within this phase, namely Alonella excisa (Fischer, 1854), Leydigia leydigi (Schoedler, 1858), and Graptoleberis testudinaria (Fischer, 1854) (Fig. 4).

\section{CAZ IV 6200 - 3900 cal yr BP (2420 - $2350 \mathrm{~cm}$ bls)}

This period was characterized by a major change in the structure of the cladoceran community. Only one pelagic species, i.e. Bosmina longirostris, persisted with an average abundance of ca. 38\%. Littoral species dominated for the first time through the history of the lake, especially those favoured by higher trophic status of the water. The most abundant of these species were Alona rectangula (Sars, 1862) (35\%) Acroperus harpae (10\%), Alonella excisa (9\%), and Pleuroxus trigonellus (8\%).

\section{CAZ V 3900 - 1500 cal yr BP (2350 - $1730 \mathrm{~cm}$ bls $)$}

The flourishment of both pelagic and littoral cladoceran species characterized this period. The upper and lower boundaries of this phase were marked by an increase in the abundance of Alona rectangula and Chydorus sphaericus. These two species together with Bosmina longirostris accounted for over $75 \%$ of all cladocerans (Fig. 4). The early stages of CAZ V was marked by the disappearance of pelagic species associated to lower trophic status waters, i.e. Bosmina (E.) longispina and Bosmina (E.) coregoni, and by the decline of Alona rectangula and Chydorus sphaericus. In the second half of this phase, the abundance of planktonic species increased again: Bosmina (E.) coregoni and Bosmina (E.) longispina reached $17 \%$ and $11 \%$, respectively, of the whole cladoceran remains.

\section{CAZ VI 1500 cal yr BP - present (1730 - $1380 \mathrm{~cm}$ bls)}

This phase was characterized by a clear decline in the abundance of Cladocera, namely from an average of 27000 ind. $\mathrm{cm}^{-3}$ in phase $\mathrm{V}$ down to 7000 ind. $\mathrm{cm}^{-3}$ in phase VI. Pelagic species (Bosminidae) dominated and

Tab. $1 .{ }^{14} \mathrm{C}$ dates from Lake Jelonek sediments.

\begin{tabular}{|c|c|c|c|c|c|}
\hline Sample name & $\begin{array}{l}\text { Depth } \\
\text { (cm bls) }\end{array}$ & $\begin{array}{l}\text { Type of } \\
\text { dating }\end{array}$ & y number & ${ }^{14} \mathrm{C}$ yr BP & cal yr BP \\
\hline Jelonek-1-1450* & 1450 & AMS & GdA-823 & $172 \pm 30$ & $\begin{array}{l}340-302(17.4 \%) \\
276-185(50.9 \%)\end{array}$ \\
\hline Jelonek-2-1550* & 1550 & AMS & GdA-824 & $417 \pm 30$ & $560-484(86.7 \%)$ \\
\hline Jelonek-3-1660* & 1660 & AMS & GdA- 825 & $1382 \pm 35$ & $1405-1311(95.2 \%)$ \\
\hline Jelonek-4-2060* & 2060 & AMS & GdA-826 & $1742 \pm 35$ & $1782-1606(95.4 \%)$ \\
\hline Jelonek-5-2120 & 2120 & AMS & GdA-827 & $1647 \pm 35$ & $1496-1596(68 \%)$ \\
\hline Jelonek-6-2260 & 2260 & AMS & GdA-828 & $2222 \pm 35$ & $2181-2307(68 \%)$ \\
\hline Jelonek-7-2350* & 2350 & AMS & GdA-829 & $3462 \pm 35$ & $3883-3691(95.4 \%)$ \\
\hline Jelonek-8-2380* & 2380 & AMS & GdA-830 & $4222 \pm 40$ & $\begin{array}{l}4909-4839(38.5 \%) \\
4895-4676(56.9 \%)\end{array}$ \\
\hline Jelonek-10-2480* & 2480 & conv. & Gd-30100 & $6702 \pm 180$ & $7922-7322(93.3 \%)$ \\
\hline Jelonek-11-2540* & 2540 & conv. & Gd-30098 & $7852 \pm 120$ & $9048-8578(95.4 \%)$ \\
\hline Jelonek-12-2560 & 2560 & conv. & Gd-15878 & $8602 \pm 140$ & $9499-9857(68 \%)$ \\
\hline Jelonek-13-2580* & 2580 & AMS & GdA-832 & $10252 \pm 50$ & $12219-10814(94.1 \%)$ \\
\hline Jelonek-14-2600* & 2600 & AMS & GdA-833 & $10882 \pm 60$ & $12948-12737(95.4 \%)$ \\
\hline Jelonek-15-2660* & 2660 & AMS & GdA-834 & $10832 \pm 60$ & $12872-12713(95.4 \%)$ \\
\hline Jelonek-17-2705* & 2705 & AMS & GdA-836 & $13192 \pm 70$ & $13221-15693(95.4 \%)$ \\
\hline
\end{tabular}

bls, below lake surface; *samples included in the age-depth model; ${ }^{\circ}$ samples excluded from the age-depth model because of stratigraphical inconsistencies; AMS, Acceleration Mass Spectrometry; conv., conventional ${ }^{14} \mathrm{C}$ dating. 
accounted for about $60 \%$ of total cladoceran abundance. The contribution of Alona rectangula and Chydorus sphaericus significantly declined, accounting only for $8 \%$ and $6 \%$ of the total abundance, respectively (Fig. 4).

\section{Pollen}

Palynological taxa that are considered as indicators of water fertility, e.g. Nymphaea (L.), Nuphar (Sm.) or Potamogeton (L.) occurred at small percentages $(<2 \%)$ throughout the entire stratigraphic profile, and therefore could not be used to reconstruct the trophic evolution of Lake Jelonek (Filbrandt-Czaja, 2009). Based on the analysis of pollen taxa which are considered as indicators of human activity four so-called human colonization phases were distinguished (Fig. 5).

Pollen showed first evidence of human activity in the basin of Lake Jelonek during the Atlantic period, which identifies the first settlement phase (ca. $7.8-3.85 \mathrm{cal} \mathrm{kyr}$ BP between 2470 and $2350 \mathrm{~cm}$ bls). The phase covered the period of Mesolithic and Neolithic economic recovery and is characterized by a decline of elm (by 6\%), oak (by $5 \%$ ) and ash (by $2 \%$ ), along with an increased abundance of pine (Fig. 5). The presence in this core section spores of fern (Pteridium aquilinum (L.) Kuhn), a fern species occurring on soils containing ash (Tinner et al., 2000), confirms the presence of human settlements in the region. At the end of this phase, the first pollen grains of ribwort plantain (Plantago lanceolata (L.)) were identified. However, indicators of anthropic pressure occurred with a relatively low percentage in this core section.

The beginning of the second settlement phase (3.6 2.9 cal kyr BP, $2300-2140 \mathrm{~cm}$ bls) coincided with the Bronze Age. This period was represented in the pollen diagram (Fig. 5) by deforestation, in particular a decline of hornbeam (Carpinus betulus (L.)) as well as oak (Quercus (L.)), elm (Ulmus (L.)), linden (Tilia (L.)) and hazel (Corylus avellana (L.)). Reduction in the number of mesophilous deciduous trees was probably connected with the objective of settlers to acquire fertile lands overgrown with forests. This period was also characterized by an increased content of mugwort pollen (Artemisia (L.)), a ruderal plant which indicates presence of crops as it was a common weed of primitive cereal crops (Behre, 1981). The increase in the content of heather (Calluna vulgaris (L.) Hull) pollen along with the presence of common ju-

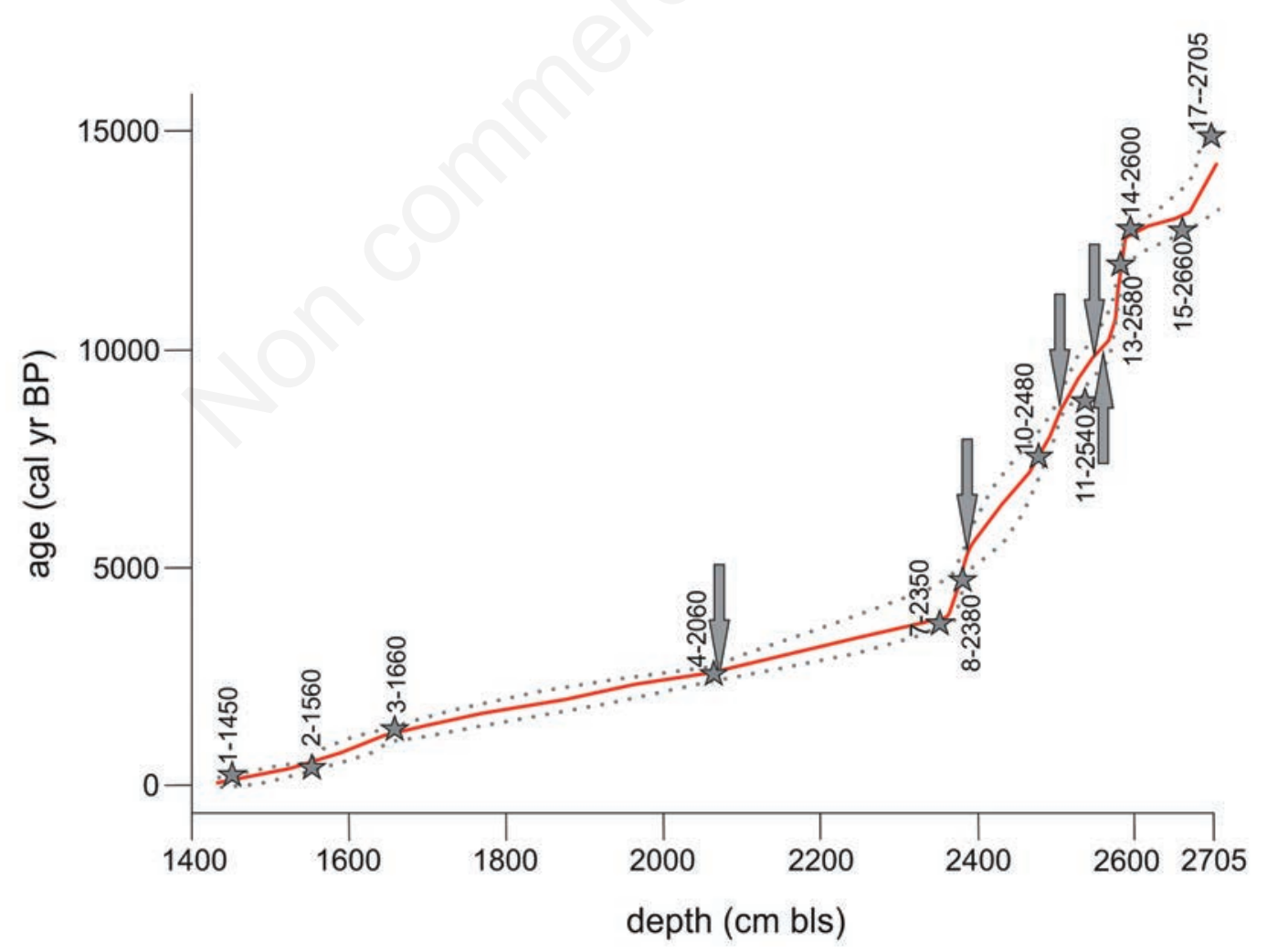

Fig. 3. Age-depth model based on the ${ }^{14} \mathrm{C}$ dating of Lake Jelonek sediments, showing sediment accumulation from Late Glacial to current times. Stars indicate ${ }^{14} \mathrm{C}$ date (see Tab. 1), and arrows point the chronostratigraphical (pollen) borders according to Mangerud et al. (1974) and Walanus and Nalepka (2010). 
niper (Juniperus communis (L.)) and broadleaf/hoary plantain (Plantago (L.) major/media) pollen indicate the presence of canopy gaps caused by cattle grazing, as well as an increase in the area of dry pastures. The end of the second settlement phase was characterized by a substantial increase in the abundances of hornbeam (Fig. 5).

The third settlement stage encompasses the Iron Age (ca. 2.8 - $1.7 \mathrm{cal} \mathrm{kyr} \mathrm{BP,} \mathrm{2110-1790} \mathrm{cm} \mathrm{bls)} \mathrm{and} \mathrm{was} \mathrm{dis-}$ tinguished by a significant increase of palynological anthropogenic indicators and by the decline of deciduous trees such as hornbeam, linden, ash and elm (Fig. 5). The most important feature of this period was the increasing abundance of cereal pollen, mainly rye (Secale cereale (L.)), and sorrel pollen (Rumex acetosa (L.)/acetosella (L.)). The upper border of this phase is marked by interruption or significant descent of percentages of all herbaceous taxa (Fig. 5).

The fourth and last settlement stage (1.3 cal kyr BP up to the present, $1660-1380 \mathrm{~cm}$ bls) began in the early Middle Age and was characterized by the increase of herbaceous taxa and the decline of deciduous tree species pollen (Fig. 5). A number of palynological taxa occurred, which

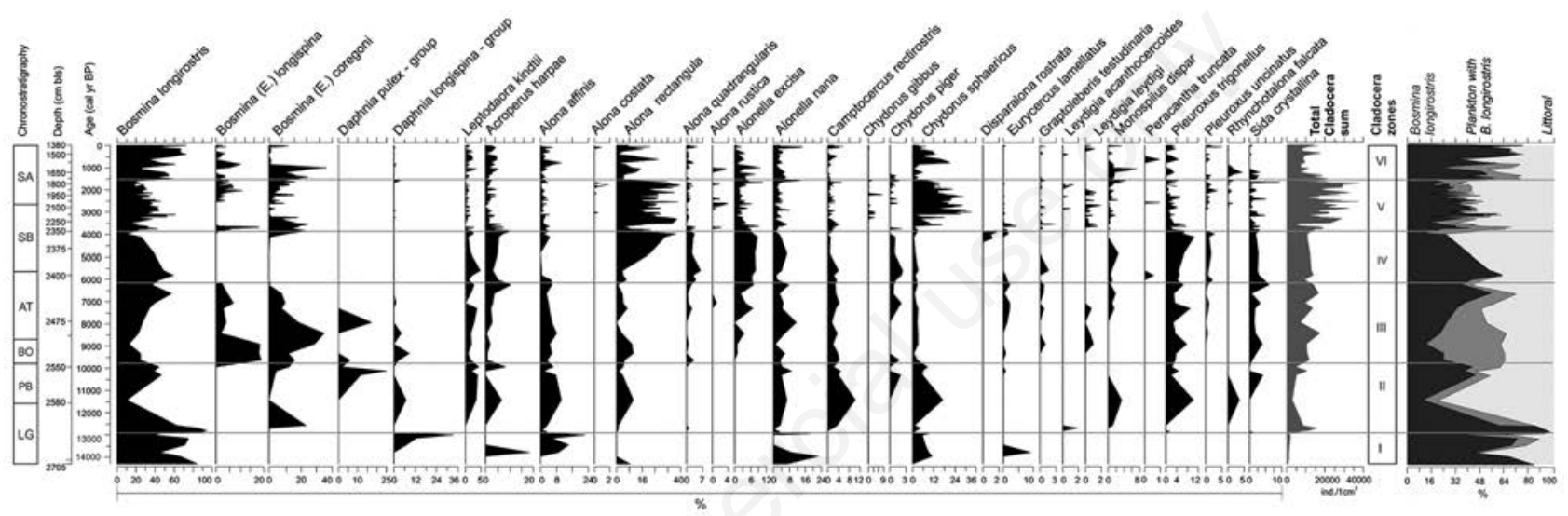

Fig. 4. Relative abundance, total Cladocera sum (as individuals $\mathrm{cm}^{-3}$ of fresh sediment), and planktonic/littoral ratio of sediment subfossil Cladocera of Lake Jelonek from Late Glacial to current times; bls, below lake surface.

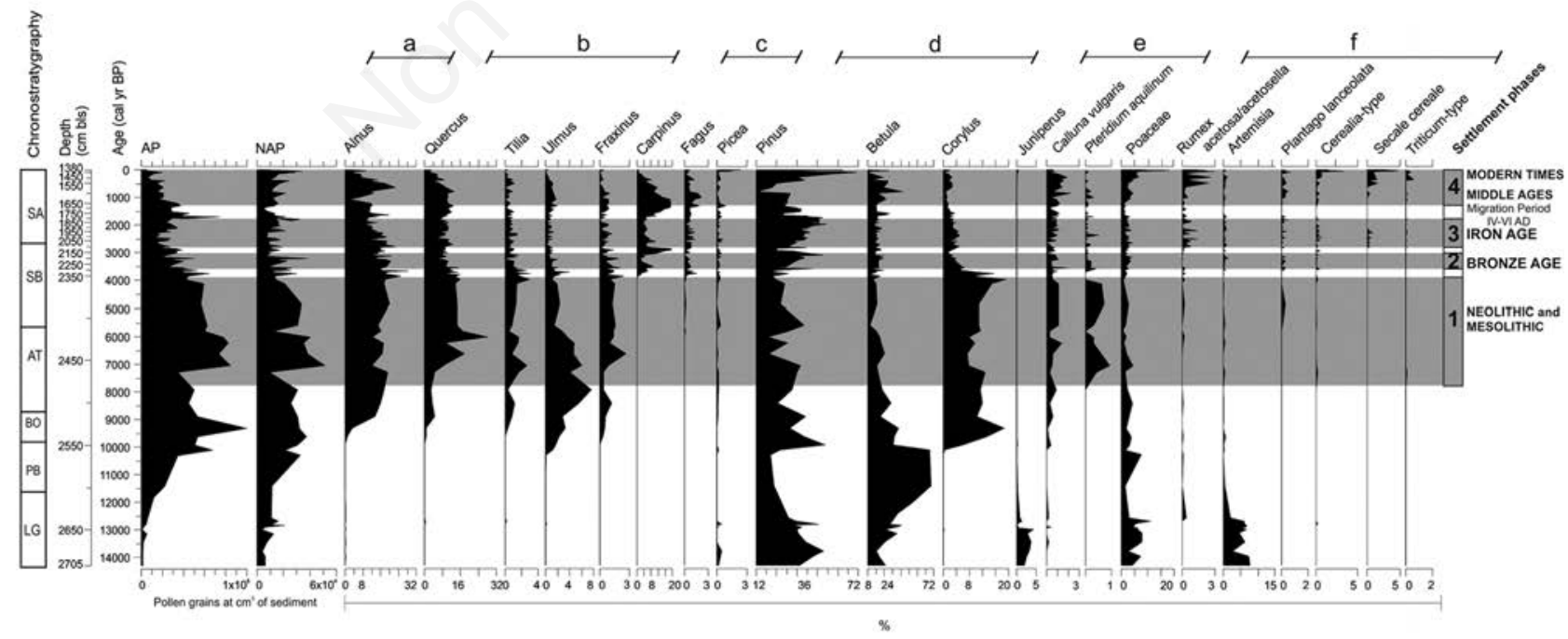

Fig. 5. Simplified, pollen diagram from Lake Jelonek. The represented taxa are subdivided into six ecological groups according to Berglund (1969): i) trees on damp soils; ii) highly competitive and shade-tolerant trees; iii) trees immigrating during late Holocene; v) scarcely competitive and light-demanding trees; v) shrubs and herbs favoured by man (apophytes); vi) herbs and graminoids introduced by man (anthropochors). AP, arboreal pollen; NAP, non-arboreal and herbs pollen; bls, below lake surface. 
are considered as indicators of grazed forests, meadows and pastures, such as Poaceae, Rumex sp., Plantago lanceeolata, Ranunculaceae, Calluna vulgaris, Campanulaceae. Pollen grains of cultivated plants, e.g. Cerealia type, Secale cereale, wheat (Triticum (L.)) occurred in large numbers.

\section{DISCUSSION}

Based on the results of geochemical analyses, subfossil Cladocera remains and pollens the trophic conditions in Lake Jelonek were reconstructed from the Late Glacial to modern times. Changes in the composition of Cladocera species, and in particular of taxa indicating higher lake trophic conditions (e.g. Bosmina longirostris, Chydorus sphaericus, Alona rectangula), enabled the assessment of the trophic history of Lake Jelonek. Changes in the afforestation rate (inferred by increasing or decreasing percentages of arboreal pollens), together with the presence of pollen of synanthropic and cultivated plants, helped to determine the type of economy (breeding, cultivation) and its impact on the vegetation cover of the lake catchment (Berglund, 1969; Aaby, 1986).

Lacustrine sedimentation in Lake Jelonek began during the Late Glacial. The pollen spectrum that characterized this time period (CAZ I, before $12900 \mathrm{cal}$ yr BP) indicates that the plant communities resembled the vegetation of the arctic tundra where heliophytes and plants tolerant to low temperature and unfavourable edaphic conditions are dominant (Filbrandt-Czaja, 2009). The low Cladocera species richness (only eight species) indicated a relatively shallow lake characterized by cold and nutrient-poor waters. The Cladocera species composition and the dominance of Bosmina longirostris at the base of the record suggested that species typically living in the open water zone were more aggregated to the lake shores. Large areas of the lake were free of plant coverage, and nutrients were available only within the shoreline zone. The content of mineral matter deposited within CAZ I amounted up to $95 \%$ of wet sediments, likely as a result of high supply of clastic material from the vegetation free shores or melting dead-ice blocks.

Species richness and abundance of cladocerans increased at the end of Late Glacial, indicating that climate and environmental conditions during the second half of this period were more suitable for zooplankton development. The more favourable climate conditions were confirmed by the rising abundances of pine pollen, although pollen of numerous herbaceous taxa was still present in large numbers. High relative abundances of Cyperaceae indicate well-developed vegetation in the littoral zone. The higher abundances of pelagic species (i.e. Bosmina (E.) coregoni) indicated a likely deepening of the lake during the stage of progressive climate warming. Average an- nual air temperature showed a clear increase by the early Holocene (Ralska-Jasiewiczowa et al., 1998), which in turn induced a substantial transformation of the vegetation within the catchment of Lake Jelonek. The first stage of succession was the growth of birch and birch-pine forests. The warming was also reflected in the succession of Cladocera species, which showed a sudden and clear increase in species diversity and abundance. Through the second half of CAZ II (11400 - 9600 cal yr BP), in addition to planktonic species (family Bosminidae), pelagic species Leptodora kindti and Daphnia pulex group appeared (Szeroczyńska, 1993; Korhola, 1999; Amsink et al., 2005), and accounted together to ca. $60 \%$ of the cladoceran assemblage. A substantial increase of planktonic species suggested high water levels during the Preboreal period. An increase of species that live in association with aquatic plants was also observed, in particular of species belonging to the family Alonidae, and species associated with warmer and clearer waters, such as Pleuroxus trigonellus and Camptocercus rectrirostris (Korhola, 1999; Amsink et al., 2005; Szeroczyńska and Zawisza, 2011). The presence of these species indicates the expansion of the littoral zone and the development of littoral vegetation. The content of organic matter in the sediment showed a gradual increase since the beginning of the Holocene, and reached $\sim 50 \%$ at the end of the Preboreal period. However, despite the prevalence of more favourable climatic and edaphic conditions during the early Holocene, the subfossil Cladocera indicate no significant changes in lake trophic status, which probably remained at the oligo-mesotrophic level (Fig. 6). This persistence of low nutrient levels in the water might have been possibly related to dilution by the rising of water level.

The development of forests, which initiated during the Preboreal period, continued through the Boreal one, and was mainly characterise by increasing pine accompanied by mesophilous trees species, namely Corylus avellana, Alnus, and Ulmus. This period was also characterized by an increased frequency and abundance of Cladocera species (at the beginning of CAZ III, 9600-8400 cal yr BP). Bosmina (E.) longispina, a species preferring welloxygenated waters with low trophic status, occurred in the pelagic zone and reached its maximum abundance through this zone. The presence of both pelagic and littoral taxa indicates that the lake was fairly deep and its littoral zone was well developed. High values of organic matter (over 50\%) deposited in the sediments during this period confirmed the richness of life in the littoral zone and an oligo-mesotrophic status (Fig. 6).

During the Holocene Climate Optimum the vegetation around Lake Jelonek was characterized by mixed deciduous forests dominated by Ulmus, Quercus, Tilia and Fraxinus. The presence of pollen grains of ivy (Hedera helix (L.)) and mistletoe (Viscum (L.)) clearly indi- 
cates mild winters and warm summers (Iversen 1944, Troels-Smith 1960). The Atlantic period (CAZ III and CAZ IV, 8400-5800 cal yr BP) manifested in the Cladocera community by the dominance of species with higher edaphic requirements (Bosmina longirostris), and of species that usually occur in association with aquatic plants (e.g. Pleuroxus trigonellus and Acroperus harpae, both belonging to the family Chydoridae). Such a cladoceran assemblage indicates a probably increase in lake trophic conditions up to mesotrophic levels (Fig. 6). It is possible that the increase in the trophic status of Lake Jelonek was the result of the first stage of human settlement, which was discriminated on the basis of palynological evidences at the end of the Atlantic period. In fact, this period corresponds to the Mesolithic settlement, which, however, was characterized by little groups of settlers that generally had little impact on the existing water bodies (Filbrandt-Czaja, 2009). The economic activity of Mesolithic tribes of hunters mainly focused on forested areas where they cleared the undergrowth with fire, aiming of chasing out the game and intensify the growth of herbaceous vegetation that served as food for deer (Latałowa, 1994, 2003; Filbrandt-Czaja, 2009). It seems likely, therefore, that the increased trophic status of Lake Jelonek during the Atlantic period was mainly related to natural processes associated with favourable climate conditions (Zawisza and Szeroczyńska, 2007) rather than to human activity. Since the beginning of the Subboreal period, the Neolithic human impact was much more evident in the sedimentary record of Lake Jelonek, even though transformation of the natural environment by Neolithic groups of settlers still remained small, as the main subsistence strategy was still based on hunting and gathering (Latałowa, 2003, 2007; Filbrandt-Czaja, 2009). Nevertheless, human activity within the lake catchment was reflected by the succession of subfossil Cladocera, by a higher abundance of species that prefer nutrient rich water (e.g. Alona rectangula), and by the disappearance of pelagic species that prefer waters with a lower trophic level (Bosmina (E.) longispina and Bosmina (E.) coregoni). During this period, the lake was probably in mesotrophic conditions (Fig. 6).

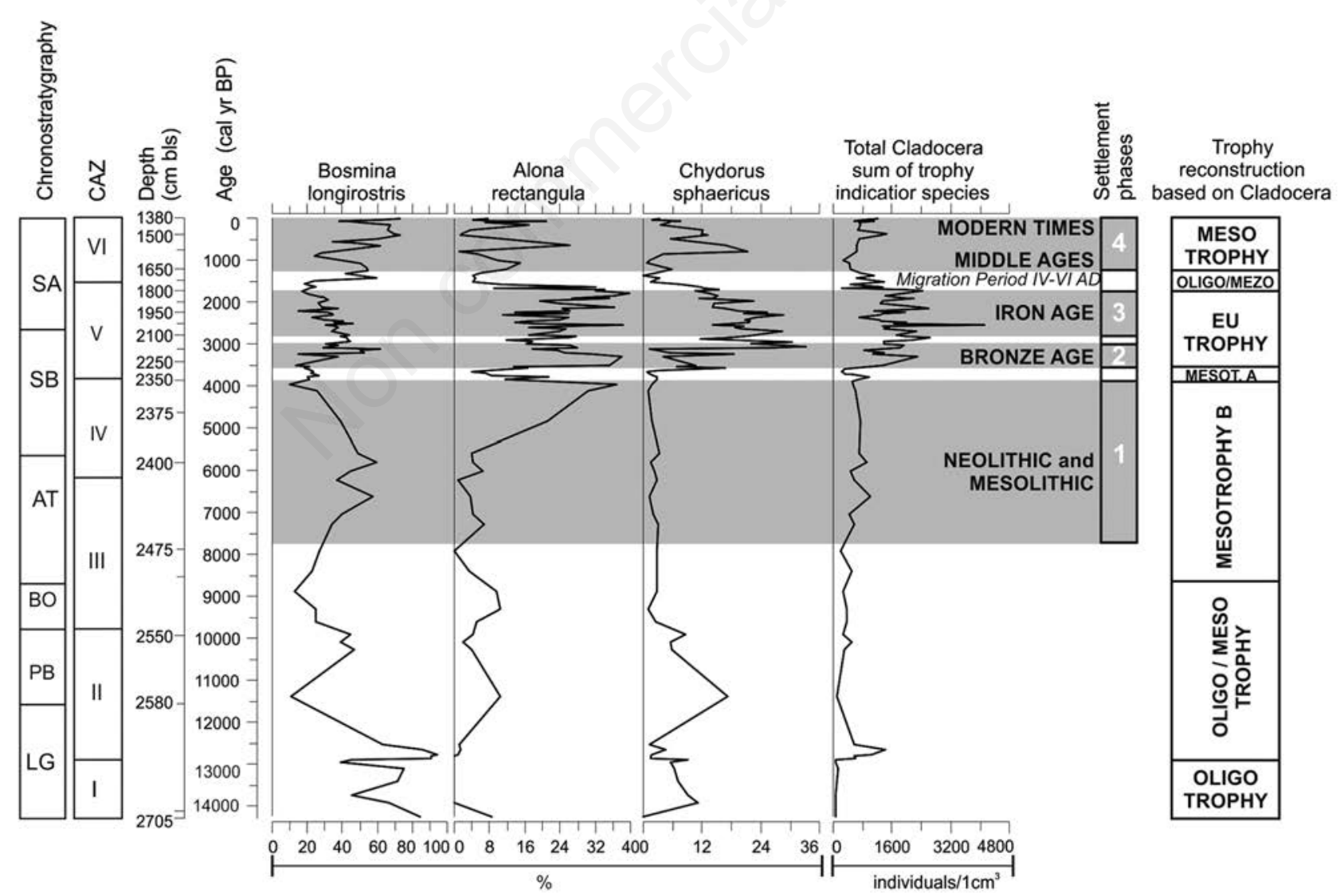

Fig. 6. Comparison of relative abundances of Cladocera species indicator of lake trophic status (i.e. Bosmina longirostris, Alona rectangula, Chydorus sphaericus) and total Cladocera abundance sum with settlement phases identified by pollen analyses. Trophic reconstruction based on subfossil Cladocera analysis. CAZ, Cladocera Assemblages Zones; bls, below lake surface. 
Between 3850-3600 cal yr BP, Cladocera species preferring low trophic conditions, such as Bosmina (E.) coregoni and Bosmina (E.) longispina (Hofmann, 1977; Korhola, 1999; Brancelj et al., 2009; Zawisza et al., 2016) further decreased, while Alona rectangula declined. Such changes in the zooplankton community indicate a recession in the trophic status of Lake Jelonek back to oligomesotrophic levels, which was most likely related to a gap in the human colonization process (between settlement phase 1 and 2), which was inferred based on the pollen evidence (Fig. 6).

Through the middle and late Subboreal period, there were substantial changes in the cladocerans succession (CAZ V). Whereas Alona rectangula and Chydorus sphaericus increased during this period (reaching the highest values in the profile), Bosmina (E.) coregoni significantly decreased, and Bosmina (E.) longispina disappeared from the record. Such species composition suggests that the lake was affected by an eutrophication process at the time, probably caused by an increased supply of nutrients into the water. The increasing curve of species considered indicators of increased trophic status (Chydorus sphaericus, Alona rectangula) was perfectly synchronous with the second and third settlement stages. i.e. during the Bronze and Iron Age, respectively, which both were determined based on palynological analysis (Fig. 6). The occurrence of grasses (Poaceae), Plantago lanceolata, Plantago major/media, Rumex sp. suggests that livestock played an important role in the human economy. Most likely they were grazed in thinned forests where large areas were covered with heather, cow wheat (Melampyrum (L.)), and bracken. These activities played a major role during the Bronze and Iron Age (FilbrandtCzaja, 2009), and continued during the Roman influence (Wielowiejski, 1981). During this time humans likely settled close or around Lake Jelonek, so that cattle breeding and other human activities resulted in an increased supply of nutrients to the lake, which increased the lake productivity up to eutrophic conditions through CAZ V. The increase in the organic matter content in the sediments layers of Lake Jelonek deposited during this period offers additional support to the interpretation of increased lake trophic status.

It is important to mention that significant changes in pollen spectra were recorded toward the end of the second settlement, especially consisting in an increasing abundances of hornbeam trees. This was high probably related to the colonization of abandoned fields and grazing lands by this arboreal taxon, which suggests that settlers abandoned the environs of Lake Jelonek. The recovery of the forest cover marked a discontinuity in the colonization, which lasted for around 150 years between phase 2 and 3.

The second half of the Subatlantic period, correspon- ding to the Migration Period at the beginning of CAZ VI, was characterized by a significant decrease in the abundance of Cladocera species. In particular, the frequency of species indicating high trophic status declined (i.e. Alona rectangula and Chydorus sphaericus), whereas the contribution of pelagic species Bosmina (E.) longispina and Bosmina (E.) coregoni increased. Such a species assemblage indicate a reduction in the trophic status of Lake Jelonek down to mesotrophic conditions, which persisted till present day. The improvement of the lake water quality was probably associated with human populations abandoning the Lake Jelonek basin. This process began about 1600 years ago in the period referred to as "pre-modern human migration" (Guy, 2007; Kobyliński, 2015). Significant regression of colonization between IV-VI century $\mathrm{AD}$ and the related forest regeneration, were reflected by the recovery of forest species and by a major decline of all herbaceous plants. Indicators of human occupation dropped to a minimum, which outline an encroachment of broadleaf forest dominated by hornbeam on areas abandoned by man.

The fourth settlement phase (Fig. 6) began during the early Middle Age and continued to present day. The pollen sequence from Lake Jelonek indicates that human activity through the early Middle Age was accompanied by land deforestation, probably associated with land reclamation for grazing and cereal cultivation. The high content of cereal pollen clearly indicates an increased intensity of colonization compared to the previous period, as well as the dominant role of cereal crops in the human diet. However, according to archaeological research, the region of Lake Jelonek was sparsely populated during the Middle Age (Wawrzeniuk, 2005). Probably, temporal human settlements characterized this time period (Woźny, 2005), which may imply a significant decrease in the amount of biogenic substances delivered to the lake. Indeed, a considerable decline of Alona rectangula and Chydorus sphaericus, both indicators of high trophic status, offer further support for the inference of small human populations. Historical data suggests that the impact of human colonization in the vicinity of Lake Jelonek gradually increased since the $15^{\text {th }}$ century (Chudziak, 2000). Maps from the late $18^{\text {th }}$ century (Schrötter maps) show that at that time the lake was surrounded to the north and northeast by arable fields and meadows, as well as by pine forests to the south and west. The land-use change affected the structure of Cladocera zooplankton, which consisted in the decrease of species usually associated with oligotrophic clear waters, such as Bosmina (Eubosmina) and Alona affinis.

The most extensive deforestation in the region of Lake Jelonek occurred in the first half of the $19^{\text {th }}$ century (Ślaski, 1951), i.e. in the period associated with the uppermost sediments layer (CAZ VI). Abundance of species 
that usually occur in nutrient rich waters (Bosmina longirostris and Alona rectangula) increased at that time. Since the early $20^{\text {th }}$ century the lake has been surrounded again by a dense forest (Broda, 2000). Afforestation represent the major land use change since then, and has resulted in a considerable isolation of the lake from the impact of human economic activity. After the lands around Lake Jelonek were abandoned by the local population, the nutrient input to the lake decreased considerably. This allowed the beginning of a process of so-called self-purification of the lake, which finally returned to present mesotrophic conditions.

\section{CONCLUSIONS}

The environmental and ecological development of Lake Jelonek through the Late Glacial and the early Holocene appeared to be mainly driven by climate changes, whereas the impact human activities became prevailing over climate related factors through the mid and late Holocene. Except during its initial formative phase, Lake Jelonek permanently was a relatively deep water body, while its trophic status oscillated several times between oligo- and eutrophic level. Oligotrophic conditions prevailed from the Late Glacial to the early Holocene, while eutrophic conditions dominated during the settlement stages of the Bronze and Iron Age. During the remaining periods the lake mesotrophic conditions prevailed. Given the lake size and depth and the population density near the shores, it can be concluded that the increase in the trophic status during the Subboreal and Subatlantic period was primarily the results of human economic activity. The last century has been characterized by the extensive recovery of the forest cover, which has substantially contributed to the recovery of a mesotrophic lake status.

The results presented here provide new important information on effects of climatic changes on the Tuchola Forest area, and on the edaphic condition of its lakes during Late Glacial and Holocene. The data presented, especially those on subfossil Cladocera analysis, integrated other paleolimnological studies, thus contributing at reducing the existing knowledge gap regarding causes and mechanisms of water eutrophication during the last millennia. The present study also stressed the close relationship that exists between lake water quality and lake catchment processes. Changes in forest cover connected with human activity revealed to have played the major role in driving lake trophic changes, which was not outlined for the area of Tuchola Forest before. The results of the present study can contribute to a better understanding of effects of climate change at anthropogenic influence on long term trophic fluctuation of lakes in Northern Poland and Central Europe.

\section{ACKNOWLEDGMENTS}

This research was possible with the support of the Institute of Geological Sciences, Polish Academy of Sciences (ING PAN), Polish Ministry of Science (N N306 228039) and by the Polish - German governments (MNiSW-DAAD, 2016-2017) DAAD project.

\section{REFERENCES}

Aaby B, 1986. Trees as anthropogenic indicators in regional pollen diagrams from eastern Denmark, p. 73-94. In: K.E. Behre (ed.), Anthropogenic indicators in pollen diagrams. A.A. Balkema, Rotterdam.

Amsinck SL, Jeppesen E, Landkildehus F, 2005. Relationships between environmental variables and zooplankton subfossils in the surface sediments of 36 shallow coastal brackish lakes with special emphasis on the role of fish. J. Paleolimnol. 33:39-51.

Berglund BE, 1969. Vegetation and human influence in South Scandinavia during Prehistoric time, 12:9-28. In: B.E. Berglund (ed.), Impact of man on the Scandinavian landscape during the Late Post-Glacial. Oikos Suppl. 12:9-28.

Berglund BE, Ralska-Jasiewiczowa M, 1986. Pollen analysis and pollen diagrams, p 455-484. In: B.E. Berglund (ed.), Handbook of Holocene Palaeoecology and Palaeohydrology. J. Wiley \& Sons Ltd., Chichester.

Behre KE, 1981. The interpretation of anthropogenic indicators in pollen diagrams. Pollen et Spores 23:225-245.

Behre KE, 1986. Anthropogenic indicators in pollen diagrams. A.A. Balkema, Rotterdam: 232 pp.

Behre KE, 1992. The history of rye cultivation in Europe. Veg. Hist. Archaeobot. 1:141-156.

Bengtsson L, Enell M, 1986. Chemical analysis, p. 423-45. In: B.E. Berglund (eds.), Handbook of Holocene palaeoecology and palaeohydrology. J. Wiley \& Sons Ltd., Chichester: 869 pp.

Beug HJ, 2004. [Leitfaden der Pollenbestimmung für Mitteleuropa und angrenzende Gebiete].[Book in German]. Verlag Dr. Friedrich Pfeil, München: 542 pp.

Birks HH, Birks HJB, Kaland PE, 1988. The cultural landscape - past, present and future. Cambridge University Press, Cambridge: $521 \mathrm{pp}$.

Blaauw M, Christen JA, 2011. Flexible paleoclimate age-depth models using an autoregressive gamma process. Bayesian Analysis 6:457-474.

Błaszkiewicz M, 2006. [Szczegółowa Mapa Geologiczna Polski w skali 1:50 000 wraz z objaśnieniami - Arkusz Osiek (167)].[Map in Polish]. Państwowy Instytut Geologiczny.

Boiński M, 1992. [Osobliwości szaty roślinnej Borów Tucholskich (Przewodnik)].[Book in Polish]. Towarzystwo Miłośników Borów Tucholskich, Toruń.

Brancelj A, Kernan M, Jeppesen E, Rautio M, Manca M, Šiško M, Alonso M, Stuchlík E, 2009. Cladocera remains from the sediment of remote cold lakes: a study of 294 lakes across Europe. Adv. Limnol. 62:269-294.

Broda J, 2000. [Historia leśnictwa w Polsce].[Book in Polish]. Wydawnictwo Akademii Rolniczej im. Augusta Cieszkowskiego w Poznaniu, Poznań: 368 pp. 
Chen G, Dalton C, Taylor D, 2010. Cladocera as indicators of trophic state in Irish lakes. J Paleol. 44:465-481.

Chudziak W, 2000. [Badania archeologiczne], p. 23-30. In: W. Chudziak (ed.), [Mezoregion osadniczy Warlubie-Płochocinek: krajobraz przyrodniczy i kulturowy].[Book in Polish]. Fundacji na Rzecz Nauki Polskiej.

Erdtman G, Berglund BE, Praglowski J, Nilsson S, 1961. An introduction to a Scandinavian pollen flora. Almqvist and Wiksell, Stockholm: 89 pp.

Faegri K, Iversen J, 1989. Textbook of pollen analysis, $4^{\text {th }}$ ed. The Blackburn Press, Caldwell: 328 pp.

Filbrandt-Czaja A, 2009. [Studia nad historią szaty roślinnej i krajobrazu Borów Tucholskich].[Book in Polish]. Wydawnictwo Naukowe Uniwersytetu Mikołaja Kopernika, Torun: $131 \mathrm{pp}$.

Flössner D, 2000. [Die Haplopoda und Cladocera (ohne Bosminidae) Mitteleuropas].[Book in German]. Backhuys Publishers, Leiden: 428 pp.

Frey DG, 1986. Cladocera analysis, p. 667-692. In: B.E. Berglund (eds.), Handbook of Holocene palaeoecology and palaeohydrology. J. Wiley \& Sons Ltd, Chichester.

Gałka M, Tobolski K, Zawisza E, Goslar T, 2014. Postglacial history of vegetation, human activity, and lake-level changes at Lake Linówek in northeast Poland, based on multiproxy data. Veg. Hist. Archaeobot. 23:123-152.

Goransson H, 1986. Man and forests of nemoral broad-leafed trees during the Stone Age. Striae, 24:143-152.

Grabowska J, Zawisza E, Jaskółka A, Obremska M, 2015. Natural transformation of the Romoty paleolake (NE Poland) during the Late Glacial and Holocene based on isotopic, pollen, cladoceran and geochemical data. Quatern. Int. 386:171-185.

Guy H, 2007. Barbarian migrations and the Roman West, 376568. Cambridge University Press, Cambridge: $614 \mathrm{pp}$.

Heiri O, Lotter AF, Lemcke G, 2001. Loss on ignition as a method for estimating organic and carbonate content in sediments: Reproducibility and comparability of results. J. Paleolimnol. 25:101-110.

Hofmann W, 1977. Bosmina (Eubosmina) population of the Grosser Segeberger See during late-glacial and postglacial times. Arch. Hydrobiol. 80:349-359.

Iversen J, 1944. Viscum, Hedera and Ilex as climate indicators. A contribution to the study of the Post-Glacial temperature climate. Geologisk Föreningens Förhaandlinger 66:463-483.

Jańczak J, 1997. [Atlas jezior Polski].[In Polish]. Instytut Meteorologii i Gospodarki Wodnej. Bogucki Wydawnictwo Naukowe.

Joye SB, Smith VH, Howarth R, 2006. Eutrophication of freshwater and marine ecosystems. Limnol. Oceanogr. 51:351-800.

Juggins S, 2007. User guide C2 Software for ecological and palaeoecological data analysis and visualisation User guide ver. 1.5. Newcastle, University of Newcastle.

Kobyliński Z, 2015. The Slavs, p. 530-537. In: P. Fouracre (ed.), The New Cambridge Medieval History: 1008 pp.

Kowalewski G, 2002. [Granice Borów Tucholskich], p. 121138. In: J. Banaszak and K. Tobolski (eds.) [Park Narodowy "Bory Tucholskie" na tle projektowanego rezerwatu biosfery].[Book in Polish]. Park Narodowy "Bory Tucholskie", Wydaw. Homoni.

Korhola A, 1999. Distribution patterns of Cladocera in subarctic
Fennoscandian lakes and their potential in environmental reconstruction. Ecography 22:357-373.

Lampert W, Sommer U, 2007. Limnoecology: the ecology of lakes and streams, 2nd ed. Oxford University Press, Oxford: $324 \mathrm{pp}$.

Latałowa M, 1994. [Gospodarka mezolityczna i początki rolnictwa na obszarze polskiego Pobrzeża Bałtyku w świetle badań palinologicznych].[Article in POlish]. Pol. Bot. Se. Kraków 11:135-153.

Latałowa M, 2003. [Holocen], p. 273-308. In: K. Sadowska, S. Dybova (eds.), [Palinologia].[Book in Polish]. Wyd. Instyt. Bot. PAN, Kraków.

Latałowa M, 2007. [Gospodarka człowieka w diagramach pyłkowych], p. 171-187. In: M. Makohonienko, D. Makowiecki, Z. Kurnatowska (eds.), [Studia interdyscyplinarne nad środowiskiem i kulturą w Polsce].[Book in Polish]. Bogucki Wydawnictwo Naukowe, Poznań.

Mangerud UJ, Anderson S, Berglund BE, Donner J, 1974. Quaternary stratygraphy of Norden, a proposal of terminology and classification. Boreas 3:109-128.

McKnight TL, Darrel H, 2000. Climate zones and types. physical geography: a landscape appreciation. Prentice Hall, Upper Saddle River: 132 pp.

Nevalainen L, Luoto TP, Kultti S, Sarmaja-Korjonen K, 2013. Spatio-temporal distribution of sedimentary Cladocera (Crustacea: Branchiopoda) in relation to climate. J. Biogeogr. 40:1548-1559.

O'Sullivan PE, 1983. Annually laminated lake sediments and the study of Quaternary environmental changes. Quat. Sci. Rev.1:245-313.

Przybylak R, Majorowicz J, Brázdil R, Kejna M, 2010. The Polish climate in the European context: an historical overview. Springer, New York: 535 pp.

Ralska-Jasiewiczowa M, Goslar T, Różański K, Wacnik A, Czernik J, Chróst L, 2003. Very fast environmental changes at the Pleistocene/Holocene boundary, recorded in laminated sediments of Lake Gościąż, Poland. Palaeogeogr. Palaeoclimatol. Palaeoecol. 193:225-247.

Ralska-Jasiewiczowa M, Goslar T, Madeyska Y, Starkel L, 1998. Lake Gościąż, Central Poland. A monographic study. Szafer Institute of Botany, Kraków.

R Core Team, 2014. R: A Language and Environment for Statistical Computing. R Foundation for Statistical Computing, Vienna, Austria. Available from: www.r-project.org

Reille M, 1992. [Pollen et spores d'Europe et d'Afrique du Nord].[Book in French]. Laboratoire de Botanique Historique et Palynologie, Marseille: 520 pp.

Reimer PJ, Bard E, Bayliss A, Beck JW, Blackwell PG, Ramsey CB, Buck CE, Cheng H, Edwards RL, Friedrich M, 2013. IntCal13 and Marine13 radiocarbon age calibration curves 0-50,000 years cal BP. Radiocarbon 55:1869-1887.

Richerson PJ, Suchanek TH, Zierenberg RA, Osleger DA, Heyvaert AC, Slotton DG, Eagles-Smith CA, Vaughn CE, 2008. Anthropogenic stressors and changes in the clear lake ecosystem as recorded in sediment cores. Ecol. Applic.18: 257-283.

Schmidt R, Muller J, Drescher-Schneider R, Krisai R, Szeroczyńska K, Barić K, 2000. Changes in lake level and trophy at Lake Vrana, a large karstic lake on the Island of Cres (Croatia), with respect to palaeoclimate and anthropogenic 
impacts during the last approx. 16,000 years. J. Limnol. 59:113-130.

Smith VH, Schindler DW, 2009. Eutrophication science: where do we go from here? Trends Ecol. Evol. 24:201-207.

Smol JP, 2008. Pollution of lakes and rivers: a paleoenvironmental perspective. Blackwell Publishing Ltd., Oxford: 383 pp.

Stockmarr J, 1971. Tablets with spores used in absolute pollen analysis. Pollen et spores 13:615-621.

Stuiver M, Polach G, 1977. Reporting of 14C data. Radiocarbon 19:355-363.

Szeroczyńska K, 1993. [Analiza Cladocera w spągowych osadach jeziora Gościąż].[Article in Polish]. Pol. Bot. Se. 8:173-179.

Szeroczyńska K, Sarmaja-Korjonen K, 2007. Atlas of Subfossil Cladocera from Central and Northern Europe. Friends of the Lower Vistula Society: 84 pp.

Szeroczyńska K, Zawisza E, 2011. Subfossil faunal and floral remains (Cladocera, Pediastrum) in two northern Lobelia lakes in Finland. Knowl. Manag. Manag. Aquat. Ec. 402:1-15.

Ślaski K, 1951. [Zasięg lasów Pomorza w ostatnim tysiącleciu].[Book in Polish]. Instytut Zachodni, Poznań: 263 pp.

Tinner W, Conedera M, Gobet E, Hubschmid P, Wehrli M, Ammann B, 2000. A Palaeoecological attempt to classify fire sensivity of treesin the southern Alps. Holocene 10:565-574.

Troels-Smith J, 1960. Ivy, Mistletoe and Elm climate indicators- fodder plants. Danmarks geologiske undersøgelse: $32 \mathrm{pp}$. Walanus A, Nalepka D, 2010. Calibration of Mangeruds Boundaries. Radiocarbon 52:1639-1644.

Wawrzeniuk J, 2005. [Archeologia sredniowiecza i nowożytna Borów Tucholskich], p. 76-97. In: W. Jastrzębski, J. Woźny (eds.), [Dziedictwo kulturowe i przyrodnicze Borów Tucholskich. Stan badań i potrzeby badawcze].[Book in Polish]. Bydgoszcz-Tuchola.

Wielowiejski J, 1981. [Produkcja rolno-hodowlana], p. 315-334. In: J. Wielowiejski (ed.), [Prehistoria ziem polskich. Późny okres lateński i okres rzymski].[Book in Polish]. Ossolinum, Wrocław.

Woś A, 2010. [Klimat Polski w drugiej połowie XX wieku]. [Book in Polish]. Wydawnictwo Naukowe UAM, Poznań.

Woźny J, 2005. [Archeologia pradziejowea Borów Tucholskich], p. 61-75. In: W. Jastrzębski, J. Woźny (eds.), [Dziedzictwo kulturowe i przyrodnicze Borów Tucholskich. Stan badań i potrzeby badawcze].[Book in Polish]. Bydgszcz-Tuchola.

Zawisza E, Szeroczyńska K, 2007. The development history of Wigry Lake as shown by subfossil Cladocera. Geochronometria 27:67-74.

Zawisza E, Zawiska I, Correa-Metrio A, 2016. Cladocera community composition as a function of physicochemical and morphological parameters of dystrophic lakes in NE Poland. Wetlands 36:1131-1142. 